\title{
How to Minimize the Fabric Waste in Fashion Industries
}

\author{
Sicilia Sawitri \\ Universitas Negeri Semarang \\ Home Economics Department \\ Indonesia \\ sicilia.sawitri@mail.unnes.ac.id
}

\begin{abstract}
The technology develops rapidly. It may cause the advantages or disadvantages in every things. The effect can also in fashion industry. In Indonesia or another country, fashion industries had rose rapidly, such as garment industries which produce men's, women's and children apparels in big quantity. Fashion Industries can be done in every place, at home is call small industry or at factory it call big industry. Those fashion industries beside produce apparels also produce fabric wastes. The waste as we know, bring some problems to everybody. Fabric wastes may cause garbage everywhere. If someone burns the fabric wastes, it can make air pollution and will made our earth damage. What will we do now? We have to minimize fabric waste. We can try to produce fashion by using zero waste pattern making, change fabric wastes into something useful, by creating into some handy crafts, we can reduce the old apparel and change to a new one. Who will be responsible for this program? Goverment, vocational school, businessmen, citizen who care about the clean environment.
\end{abstract}

\section{Keywords-Minimize, fabric waste, fashion industries}

\section{INTRODUCTION}

The technology develops rapidly. It may cause the advantages or disadvantages in every things. The effect of develping technology can also in fashion industry. In Indonesia or another country, fashion industries had rose rapidly, such as garment industries which produce men's, women's and children apparels in big quantity. Fashion Industries can be done in every place, at home is call small industry or at factory it call big industry. Those fashion industries beside produce apparels also produce fabric wastes. The waste as we know, bring some problems to everybody. Fabric wastes may cause garbage everywhere. If someone burns the fabric wastes, it can make air pollution and will made our earth damage. What will we do now? We have to minimize fabric waste. We can try to produce fashion by using zero waste pattern making, change fabric wastes into something useful, by creating into some handy crafts, we can reduce the old apparel and change to a new one. Who will be responsible for this program? Goverment, vocational school, businessmen, citizen who care about the clean environment.

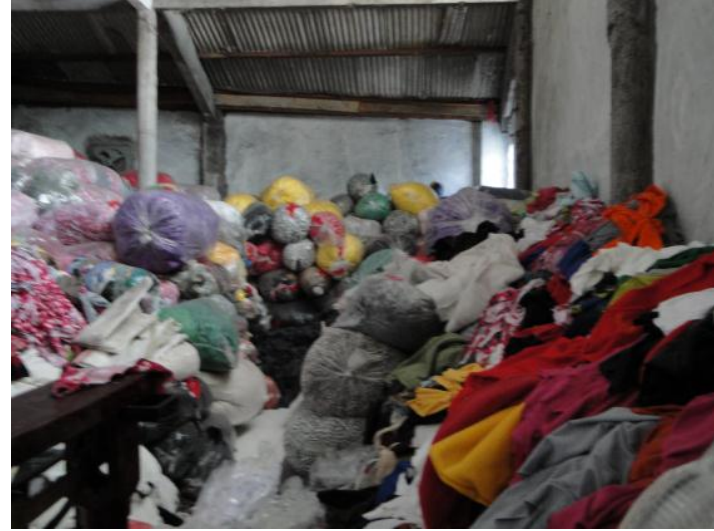

Fig. 1. Fabric waste. Think about it

\section{FASHION INDUSTRIES}

There are several fashion industries where can created fabrics wastes, such as: haute couture, couturier business, boutique, ready to wear (mass production).

\section{Haute couture}

An haute couture collection has profound effect on the fashion world as presented by the top disgners of London, Paris and Rome (Dunn, 1974:86). Haute couture comes from the French language. Haute couture business is an exclusive fashion business, both in terms of design and materials and finishing techniques. A unique design is intended merely for one customer with good quality and exclusive material given as well as finishing technique needs a special attention; thus the price of a fashion produced in haute couture is certainly expensive. However, the business of ready-to-wear and mass production are sometimes claimed to produce haute couture fashion

\section{Couturier business}

Couturier business at first it is only a side-job for housewives to spend their spare times as well as to earn some additional income for family. It is one of types in the field of fashion businesses for individuals, in this case the customer comes and is measured to fit the appropriate size and then the clothes are produced. All jobs starting from measuring, creating patterns, and cutting to the final product they perform by themselves. Sri Wening and Sicilia Sawitri (1994:95) 
defined couturier (dress maker) as the individual fashion business type by measuring each customer particularly for women and children. They, generally, use simple equipment. The system used in the couturier business is semi tailoring, i.e. a fashion finishing technique with merely veering process. Service products usually made are women and children clothing.

Tailor business is a service business which receives orders with tailoring systems, typically working on menswear. Tailoring system is a sewing technique in which either the outside and inside of the cloth produces is neatly covered with upholstery fabric (lining). Fashion models in tailor business are generally coats or semi-coats.

Boutique is a fashion business that sells clothes and accessories (Dunn, 1978: 88). The quality of these clothes is usually good, smooth and neat stitching, and limited production number. Accessories that are available in the boutique include an assortment of jewelry, shoes, sandals, handbags, scarves, belts and many others. At the boutique businesses, they do not receive sewing orders; the stocks are supplied by other companies that produce clothes and accessories. Type of clothing sold in the boutique is ready-to-wear fashion.

Ready to wear orMass Production Clothing Business provides customers with large quantities and produces readymade clothing in large quantities and use standard sizes (S, M, $\mathrm{L}, \mathrm{XL}, \mathrm{LLL}$ etc.). The materials that are generally used are less expensive materials, thus the price can be affordable by the lower classes. The selected trends are generally adapted from the clothing worn by famous people. The use of materials with low price and simple techniques with a machine enable to produce cheap-priced clothes. Mass production conducted in the industry is generally called garment, while production conducted in houses is called convection.

\section{THE WAY TO MINIMIZE FABRIC WASTE}

There are some ways to minimize the fabric waste from fashion industries, such as using zero waste pattern making technique, create some handicrafts by using some technique (patch work, quilting, weaving, reduce and recycle)n and refashion.

\section{Zero waste fashion pattern making.}

Zero waste fashion pattern making is a fashion which in the production process does not product any waste and some time zero it means that no waste. Zero waste is a philosophy. The Zero waste fashion is not a new material, but it is a new technique in fashion.

\section{Creating Some Things From Fabric Waste}

Actually fabric waste can be crated in to many handicrafts In small business, we can create some things new from fabric wastes. By using some techniques the fabric waste can be changed in some things useful, for examples: photo frames, pillow cases, cusshion cases, bags, dolls, mat, telephone covers, refrigerator coverts. We can apply some techniques to create those things new, such as: appliqué, quilting, mozaic, weaving and patch work technique.

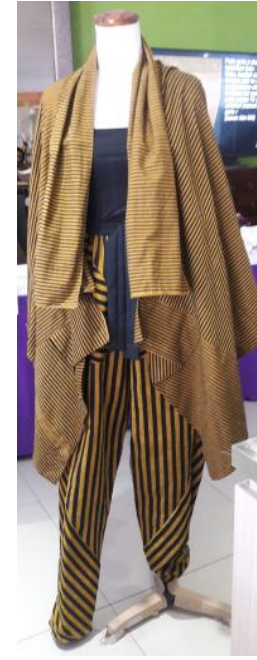

Fig. 2. Fashion using Zero Waste Pattern (Aryani Widagdo, 2017)

\section{Applique Technique}

Applique is one of decorating fabric by applying small fabric on large fabric, and using decorative stichs (Sawitri, 1982: 15). Applique technique is basically a sewing craft, by applying a small fabric as decorative design on other large fabric, using sewing machine or hand decorative stich. Inspiration for applique design can be found in many sources, among other coloring books greeting cards and everyday objects. A typically simple design can consist of a central motif cut form a single piece, or perhaps made up of two or more pieces (Reader's Digest, 1979: 192).

Applique technique can be applied on any kind of linen equipment, such as: table clothes, pillow case, cushion cases, table mats, curtain, aprons, children clothes and handicrafts.

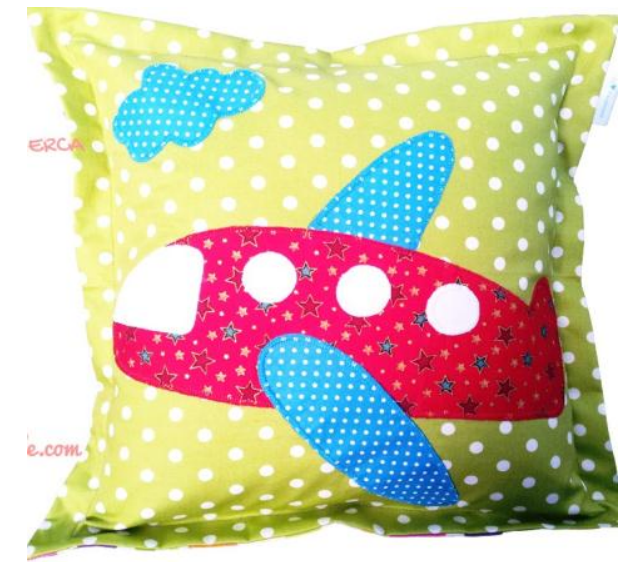

Fig. 3. Application technique on a Cushion (Farahikha.wordpress.com)

\section{Patchwork Technique}

Patchwork technique is the joining of pieces of fabric to form a larger unit of fabric (Reader's Digest, 1979: 208)..The most interesting characteristic of any patchwork is he design that the joined fabric pieces produce. Some patchwork designs are simple and easy to analyze, others are so intricate that it is hard to tell how they were achieved. 
The process in creating new product by using patchwork technique, are: desided the purpose of the patchwork and create the design for a new product.

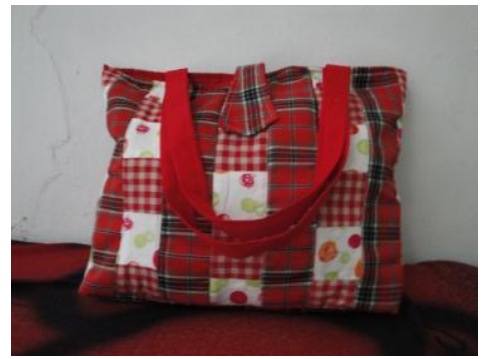

Fig. 4. Patch Work Technique

\section{Quilting Technique}

Quilting technique is one of the techniques which is using a piece of sponge under the fabric and tying them by using hand or machine stitches. There are two types of quilting techniques, they are: Italian type and Britain type. In the Italian type, the stiches are around the motif, but in Britain type the stiches are geometrical.

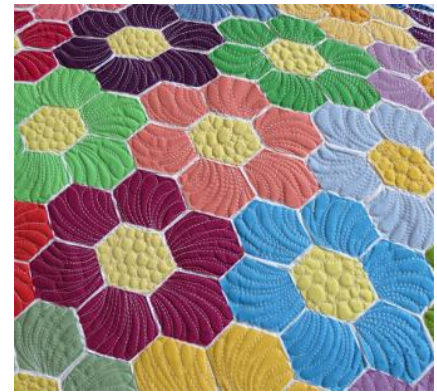

Fig. 5. Quilt technique (Pinterest)

\section{Weaving Technique}

Weaving is on of techniqe to produce the fabric. Before weaving the fabric waste were joined by using sewing. Weaving is the interlacing of two sets o yarns which are interlaced at right angles to each other (Katz, Colleen, et al, 1980: 318). There are three basics of weaving, the first is plain weaving, the second is twill weaving and the third is satin weaving.

Those three basic weavings can be created to another variation.

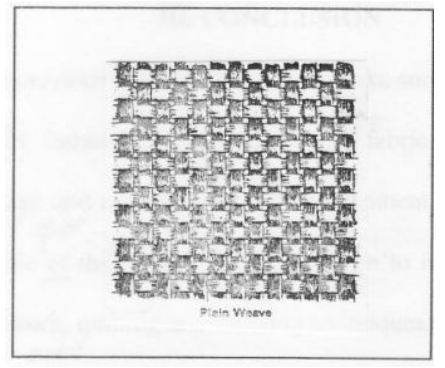

Fig. 6. Plain Weaving Pattern

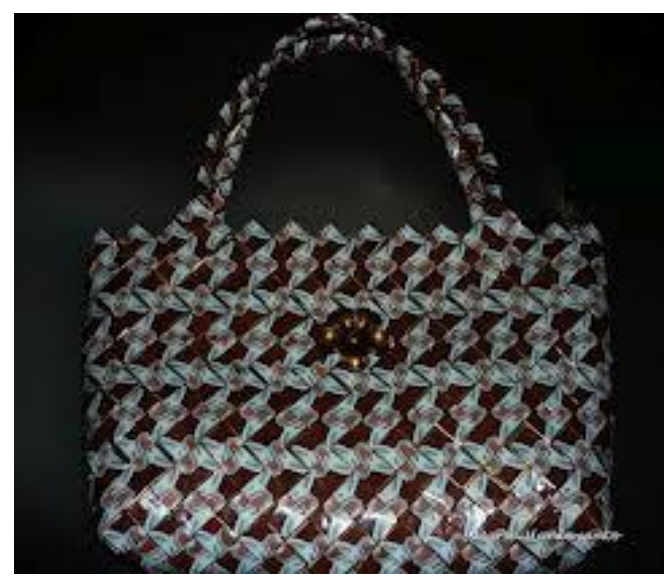

Fig. 7. The variation of weaving.

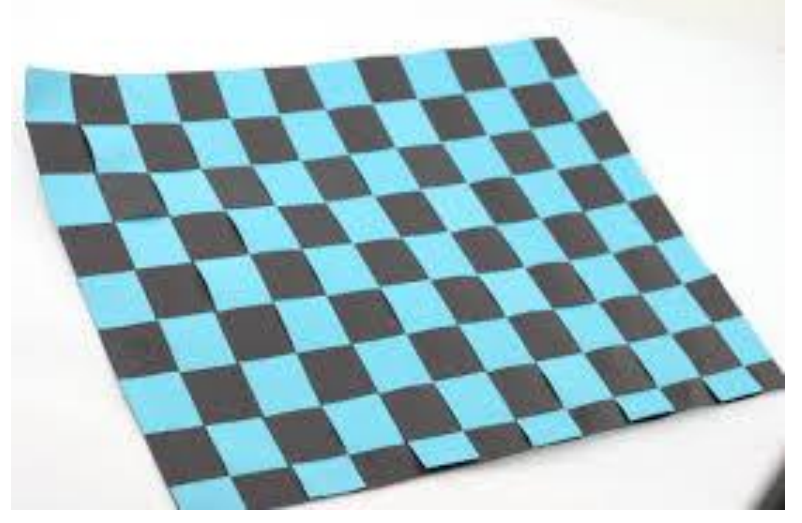

Fig. 8. Plain weaving (wikihow)

\section{Refashion the old apparel into new design}

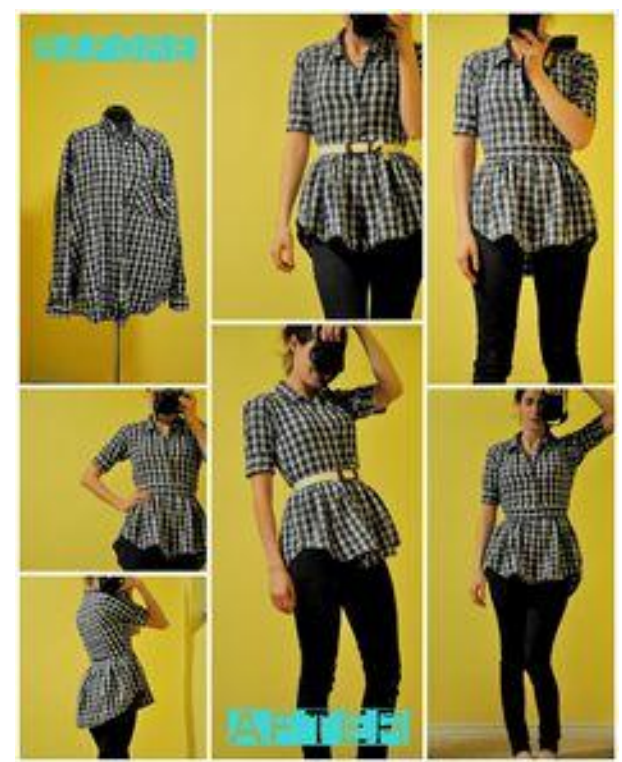

Fig. 9. Refashion (Pinteres) 


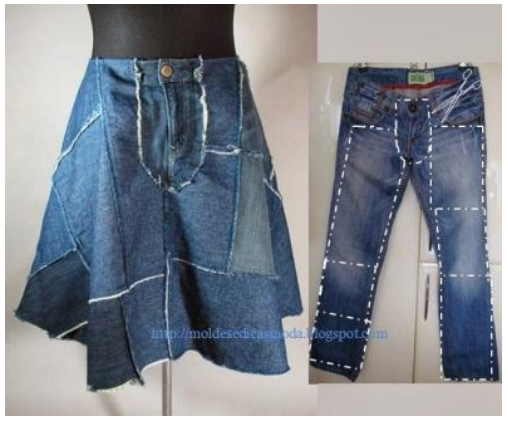

Fig. 10. Refashion ( Worderful DIY)

Another techniqe to minimize the fabric waste, are creating fashion accessories, such as: broch, bandana,

\section{CONCLUSION}

Based on the previous information, we can make some conclusions, as follow:

1. Fashion industries produce clothes in many varietis.

2. Fashion industries also produced fabric waste, which have some effects, such as: garbage and air pollution.

3. Being responsible: government, societies, women organizaation PKK, Vocational school., citizen who care about fabric waste.
4. Creativities of people are needed dto minimize fabric waste from a garmen industri (smalll or big)

5. Some ways to minimized the fabric waste from fashion industries, were:

a. Using zero waste pattern making

b. Creating handicraft by using applique, patchwork, quilt and weaving technique.

c. Refashion the old apparel to the new one.

\section{REFERENCE}

[1] American Fabrics and Fashion Magazine. 1980. Encyclopedia of Textiles. USA: Prentice-Hall Inc, Englewood Cliffs. NJ.

[2] Dunn.GM, 1974. Fashion Design. Adelaide: Rigby Limited.

[3] Hisrich, RD, Peters, MP, Shepherd DA. 2008. Entrepreneurship. New York: McGraw-Hill Companies, Inc.

[4] http://www. All peoplequilt.com/magazine-more/ merican- patchworkquilting/color-options-american- patchwork- quilting-june 2013.

[5] Reader Digest, 1980.

[6] Wening, S \&Sawitri,S. 1994. Dasar Pengelolaan Usaha Busana. Yogyakarta: IKIP Yogyakarta.

[7] Sawitri, S. 1982. Apresiasi Menghias Busana. Paper. Jakarta: IKIP Jakarta

[8] Sawitri, S. 2014. The Utilization of Fabric Waste as Raw Material in the New Small Business. Journal of Environmentally Friendly Processes, Volume 2. Issue 1. Februari 2014. Down load. 